\title{
Telaah Pemikiran Ali Mustafa Ya'qub tentang Poligami
}

\author{
Harel Bayu Faizin \\ Universitas Islam Negeri Sunan Kalijaga Yogyakarta \\ Email: bayufaizin@gmail.com
}

\begin{abstract}
This article discusses one of the always hot topics to discuss, namely Polygamy. Polygamy is a problem that is still being debated by many parties, which causes the pros and cons of the theme to arise. Do not miss the Ali Mustofa Ya'qub, who is one of the many figures made as a reference in taking legal advice. In this paper, we will explain how the method used by Ali Mustofa Ya'qub on the hadith argument related to the theme of Polygamy. This article concludes that polygamy is basically a text which states it, but it does not mean ordering it nor prohibiting it. The Prophet Muhammad did polygamy with the aim of spreading Islam, not because of sexual desire, or to show men's power over women. However, developments in the following periods turned out to be the opposite. If in the next practice, polygamy raises various cases of polygamy, it does not depend on men's justice, but rather on the ability of men (husbands) to make women (wifes) submit and surrender on behalf of their authority as husbands and heads of households. This is very different from the polygamy practice carried out by the Prophet with the motive of preaching and protecting and caring for women.
\end{abstract}

Kata kunci: poligami, Ali Mustofa Ya'qub, hadis

\begin{abstract}
Abstrak: artikel ini membahas salah satu topik yang selalu hangat untuk diperbincangkan yaitu Poligami. Poligami merupakan suatu masalah yang masih diperdebatkan oleh banyak pihak sehingga menyebabkan timbulnya pro dan kontra terhadap tema tersebut. Tidak ketinggalan dengan Ali Mustofa Ya'qub yang merupakan salah satu pakar hadis di Indonesia yang pemikirannya banyak di jadikan rujukan dalam mengambil istinbath (penetapan) hukum. Dalam tulisan ini akan dijelaskan bagaimana metode yang dipakai oleh Ali Mustofa Ya'qub terhadap dalil hadis yang berkaitan dengan tema poligami ini. Artikel ini menyimpulkan bahwa poligami pada dasarnya memang ada nash yang menyatakannya, tetapi bukan berati memerintahkannya dan tidak juga melarang. Poligami pernah di lakukan oleh Rasulullah Saw dengan tujuan syiar Islam bukan karena hasrat seksual, ataupun menunjukkan kekuasaan laki-laki atas perempuan. Akan tetapi perkembangan pada masa-masa berikutnya malah menjadi sebalik nya. Apabila pada praktek berikutnya, poligami memunculkan berbagai kasus poligami bukan bergantung pada keadilan laki-laki, tetapi lebih kepada kemampuan laki-laki (suami) untuk menjadikan perempuan (istri) tunduk dan pasrah atas nama otoritasnya sebagai suami dan kepala rumahtangga. Hal ini sangatlah berbeda dengan paraktek poligami yang dilakukan Nabi dengan motif dakwah dan melindungi serta memulikan wanita.
\end{abstract}

Keyword: poligamy; Ali Mustofa Ya'qub; hadith 


\section{PENDAHULUAN}

Islam adalah agama yang mengatur semua kehidupan umatnya, tak terkecuali mengenai kehidupan berumah tangga bagi pemeluknya. ${ }^{1}$ Dalam Islam, perkawinan tidak hanya merupakan legitimasi hubungan antara laki-laki dan perempuan semata-mata, melainkan juga sebagai wahana mewujudkan kasih sayang yang diberikan oleh Allah pada proses penciptaan-Nya yang pertama kali tersebut. Perkawinan merupakan salah satu unsur ibadah. Islam mengakui bahwa menikah merupakan penerapan salah satu sunnah Nabi SAW yang berarti bahwa melaksanakan pernikahan merupakan pelaksanaan ibadah yang merupakan sarana untuk menyempurnakan sebagian dari agama.

Salah satu di antara pembahasan perkawinan adalah masalah poligami. Poligami

\begin{tabular}{l}
\hline Abdutawab Haikal, Rahasia \\
Perkawinan Rasulullah Saw; Poligami dalam \\
Islam VS Poligami Barat (Jakarta: Pedoman \\
Ilmu Jaya, 1993), 6.
\end{tabular}

merupakan salah satu tema penting yang mendapat perhatian dari Allah SWT, sehingga tidak mengherankan jika Allah meletakkannya di awal surat an-Nisa': 1. yang menjelaskan bahwa Allah menciptakan manusia, yaitu Adam, yang satu, kemudian istrinya dan dari keduanya berkembang yang terdiri dari lakilaki dan perempuan yang banyak. Kemudian di ayat yang ketiga dari surat an-Nisa' itu satu-satunya ayat yang membicarakan masalah poligami yang perlu mendapat perhatian dari kaum muslimin semuanya.

Tidak dapat dipungkiri bahwasanya kajian mengenai poligami ini selalu menjadi suatu pembahasan yang menarik dan menimbulkan berbagai kesimpulan dalam pemahamannya. Poligami dalam Islam adalah perkara yang masih debatable dan masih diperbincangkan hingga saat ini. Satu sisi poligami ditolak dengan berbagai macam argumentasi baik yang bersifat normatif, psikologis bahkan sangat bersinggungan dengan 
ketidakadilan gender. Mereka berpendapat meskipun ada indikasi kebolehan poligami, namun itu bertujuan menghindari perilaku tidak adil dalam mengelolah harta anak yatim, itupun disertai persyaratan harus mampu berbuat adil terhadap istri-istri yang dinikahi. Sementara berbuat adil bukanlah hal mudah dan bahkan menurut mereka mustahil manusia mampu melakukannya. ${ }^{2}$ Bagi penentang Islam sendiri ada kecenderungan mengklaim poligami adalah bukti ajaran Islam dalam bidang perkawinan yang sangat diskriminatif terhadap wanita. Mereka menganggap poligamilah salah satu penyebab kemunduran dan keterbelakangan dunia Islam.

Poligami dianggap sebagai salah satu bentuk diskriminasi terhadap perempuan dan sebagai gambaran ketidaksetaraan antara laki-laki dan perempuan, karena pada dasarnya poligami itu merupakan sisa-sisa perbudakan

2 Abdurrahman I. Doi, Women in Syari"ah (Islamic Law) (Malaysia: A.S. Noordeen, 1992), 55. terhadap kaum perempuan, dimana orang-orang berkuasa seperti raja, pangeran, kepala suku, dan pemilik harta memperlakukan kaum perempuan semata-mata sebagai pemuas nafsu seksual dan pengabdi untuk dirinya. ${ }^{3}$

Islam bukanlah agama yang pertama kali menetapkan aturan poligami, dengan kata lain sebagai pelopor dalam melakukan poligami. Hal ini diperkuat dengan fakta sejarah yang menyebutkan bahwa poligami telah dipraktikkan dalam kehidupan masyarakat jauh sebelum Islam itu datang. Bahkan dikatakan bahwa sejarah poligami sama tuanya dengan sejarah manusia.

Sebelum Islam datang, bangsa Arab Jahiliyyah dalam melakukan pernikahan tidak membatasi jumlah wanita yang hendak dinikahi. Setiap orang memiliki kebebasan untuk menentukan jumlah istri tanpa ada hukum, syarat ataupun ikatan yang mengatur. Sehingga tidak heran bila

3 Nurjanah Isma'il, Perempuan dalam Pasungan, (Yogyakarta: LKIS Yogyakarta, 2003), 212. 
seseorang memiliki istri puluhan bahkan ratusan. Akan tetapi stelah Islam dating, semua itu mulai dibenahi. Poligami ada di dalam Islam tapi dengan batasan hanya empat wanita saja. Proses dimana Islam mengadopsi adat Arab pra Islam dengan mengubah beberapa hal yang bertentangan dengan nilainilai moral ajaran agama Islam disebut denga taghyir. Di dalam AlQur'an terdapat sejumlah ayat yang menjelaskan tentang poligami (QS. An-Nisa' /4: 3, 58, 129). Hadis-hadis yang berbicara tentang hal ini pun cukup banyak.

Secara garis besar, pandangan para ulama dan pemikir Islam terhadap poligami, dapat di golongkan pada tiga pendapat. Pertama, mereka yang memegangi ketidak bolehan menikahi wanita lebih dari satu, kecuali dalam kondisi tertentu. Kedua, mereka yang meyakini kebolehan menikahi wanita lebih dari satu. Sedangkan yang Ketiga berpendapat bahwa menikahi wanita lebih dari empat pun di bolehkan.
Di Indonesia, poligami merupakan salah satu isu yang sangat sensitif, apalagi jika poligami itu dilakukan oleh figur publik. Banyak kalangan yang menolak praktek ini, akan tetapi ada juga yang menyetujuinya dengan berbagai alasan yang mereka kemukakan. Salah satu ulama yang intens dalam mengkaji hukum Islam adalah Prof. Dr. KH. Ali Mustafa Yaqub, MA. (Ali) beliau lahir dari sebuah keluarga yang taat dalam menjalankan agama. Ali merupakan sosok pribadi intelektual muslim, Ali dikenal sebagai pakar Ilmu Hadis di Indonesia. Selain itu Ali adalah seorang da'i, siraman rohani yang di sampaikannya selalu menyejukan hati pendengarnya ${ }^{4}$. Ali Mustafa Yaqub masuk dalam deretan tokoh yang relatif berpengaruh dalam kancah keilmuan, banyak menyumbangkan gagasan berilian dan merupakan pakar dalam bidang hadis. Selain terbukti sudah didaulat

4 Ali Mustafa Yaqub, Sejarah dan Metode Dakwah Nabi, (Jakarta: Pustaka Firdaus, 2000), 240. 
sebagai guru besar dalam bidang hadis, kepakaran Ali Mustafa dalam bidang ini bisa dilihat dari beberapa bukunya yang sudah tersebar, misalnya Haji Pengabdi Setan. (2006), Fatwa-fatwa Imam Besar Masjid Istiqlal (2008), Kritik Hadis (2011), Setan Berkalung Surban (2014) dan Hadishadis Bermasalah (2014). ${ }^{5}$

Berdasarkan permasalahan yang telah dikemukakan, maka focus dalam penelitian ini adalah mengetahui hadis-hadis tentang poligami serta bagaimana penerapan hadis ini menurut konsep Ali Mustofa Ya'qub.

\section{PEMBAHASAN}

\section{A. Pengertian Poligami}

Kata Monogamy dapat dipasangkan dengan poligami sebagai antonim, Monogamy adalah perkawinan dengan istri tunggal yang artinya seorang laki-laki menikah dengan

5 Miski, Pemahaman Hadis Ali Mustafa Yaqub (Studi atas Fatwa Pengharaman Serban dalam Konteks Indonesia), Riwayah: Jurnal Studi Hadis 2, no. 1 (2016), $17 . \quad$ DOI: 10.21043/riwayah.v2i1.1625. seorang perempuan saja, sedangkan kata poligami yaitu perkawinan dengan dua orang perempuan atau lebih dalam waktu yang sama. Dengan demikian makna ini mempunyai dua kemungkinan pengertian; Seorang laki-laki menikah dengan banyak lakilaki kemungkinan pertama disebut Polygini dan kemungkinan yang kedua disebut Polyandry. Hanya saja yang berkembang pengertian itu mengalami pergeseran sehinggah poligami dipakai untuk makna laki-laki beristri banyak, sedangkan kata poligyni sendiri tidak lazim dipakai.

Kata poligami berasal dari bahasa Yunani secara etimologis, poligami merupakan derivasi dari kata apolus yang berarti banyak, dan gamos yang berarti istri atau pasangan. Jadi poligami bisa dikatakan sebagai mempunyai istri lebih dari satu orang secara bersamaan. 
Adapun secara terminologis, poligami dapat dipahami sebagai suatu keadaan dimana seorang suami memiliki istri lebih dari satu orang. ${ }^{6}$

Sedangkan poligami yang berasal dari bahasa Inggris adalah "Poligamy" dan disebut dalam hukum Islam, yang berarti beristri lebih dari seorang wanita. Begitu pula dengan istilah poliandri berasal dari bahasa Inggris "poliandry" dan disebut تعدّد الأزوج atau تعددالبعول dalam hukum Islam, yang berarti bersuami lebih dari seorang pria. Maka poligami adalah seorang pria yang memiliki istri lebih dari seorang wanita, sedangkan poliandri adalah seorang wanita yang bersuami lebih dari seorang pria. $^{7}$

${ }^{6}$ A. Rodli Makmun dan Evi Muafiah (ed), Poligami dalam Penafsiran Muhammad Syahrur (Ponorogo: STAIN Ponorogo Press, 2009), 15.

${ }^{7}$ Mahyuddin, Masailul Fiqhiyah (Jakarta: Kalam Mulia, 2003), 40 - 59.
Dalam Kamus Besar Bahasa Indonesia (KBBI) kata poligami diartikan sistem perkawinan yang membolehkan seseorang mempunyai istri atau suami lebih dari satu orang. Memoligami adalah menikahi seseorang sebagai istri atau suami kedua, ketiga dan seterusnya. ${ }^{8}$ Dalam pengertian umum yang berlaku di masyarakat kita sekarang ini poligami diartikan seorang lakilaki kawin dengan banyak wanita. Menurut tinjauan Antropologi sosial (Sosio antropologi) poligami memang mempunyai pengertian seorang laki-laki kawin dengan banyak wanita atau sebaliknya. Poligami dibagi menjadi 2 macam yaitu: a) Polyandri yaitu perkawinan antara seorang perempuan dengan beberapa orang laki-laki. b) Poligini yaitu perkawinan antara laki-laki

8 Departemen Pendidsikan Nasional, Kamus Besar Bahasa Indonesia Pusat Bahasa, Edisi. iv, (Jakarta: PT. Gramedia Pustaka Utama, 2008), 1089. 
dengan beberapa orang perempuan.

Dalam perkembangannya istilah poligini jarang sekali dipakai, bahkan bisa dikatakan istilah ini tidak dipakai lagi dikalangan masyarakat, kecuali dikalangan antropolog saja. Sehingga istilah poligami secara langsung menggantikan istilah poligini dengan pengertian perkawinan antara seorang lakilaki dengan beberapa orang perempuan disebut poligami, dan kata ini dipergunakan sebagai lawan polyandri. ${ }^{9}$

\section{B. Hadis-hadis tentang Poligami}

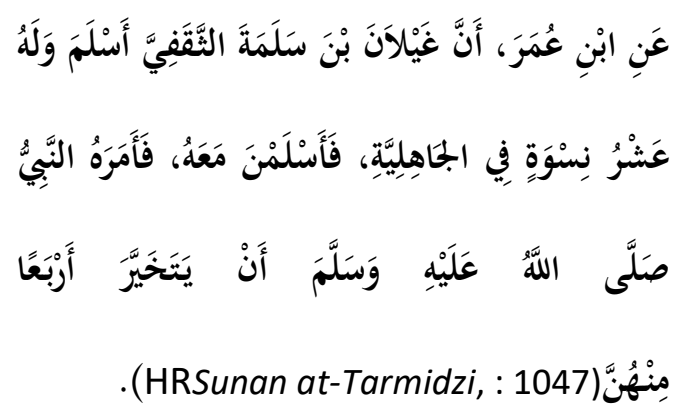

Dari ibnu Umar, bahwa Ghailan bin Salamah AtsTsaqafi masuk Islam,

${ }^{9}$ Bibit Suprapto, Liku-liku Poligami (Yogyakarta: Al-Kautsar, 1990), 71 - 72. sedangkan ia mempunyai sepuluh orang istri pada zaman jahiliyah, lalu mereka juga masuk Islam bersamanya, kemudian Nabi SAW memerintahkan Ghailan untuk memilih (mempertahankan) empat diantara mereka.

Abu Isa berkata, "Begitulah Ma'mar meriwayatkan dari AzZuhri, dari Salim, dari ayahnya."

Ia berkata, “Aku mendengar Muhammad bin Ismail mengatakan bahwa hadis ini tidak akurat. Yang benar adalah hadis yang diriwayatkan Syu'aib bin Abu Hamzah dan yang lain dari Az-Zuhri."

Ia berkata, "Aku diberitahu dari Muhammad bin Suwaid Ats-Tsaqafi bahwa Ghailan bin Salamah masuk Islam dan ia punya sepuluh istri."

Muhammad berkata, "Hadist Zuhri berasal dari Salim, dari ayahnya: 'Seorang 
lelaki dan Tsaqif menceritakan istri-istrinya'. Lalu Umar berkata kepadanya, 'Sungguh, engkau rujuk kembali istriistrimu atau aku akan melempari kuburan seperti halnya kuburan Abu Righal'."

Abu Isa berkata, "Hadis Ghailan bin Salamah diamalkan oleh sahabat-sahabat kita, di antaranya adalah Syafi'I, Ahmad, dan Ishak."10

\section{Rawi dan Sanad Hadis}

Hadis di atas diriwayatkan oleh As-Syafi'i dalam kitabnya alUm, Imam Ahmad dalam kitab Musnadnya, Abu Daud dalam kitab Sunannya, Ibnu Majah, Ibnu Hiban, dan Hakim dalam kitab mereka masing-masing.

Sementara sanadnya adalah mereka semua menerima hadis tersebut dari: Ma'mar, dari Zuhri, dari Salim, dari ayahnya.

${ }^{10}$ Muhammad Nashiruddin Al Albani, Shahih Sunan At-Tirmidzi, terj Ahmad Yuswaji, Cet I, (Jakarta: Pustaka Azzam, 2003), 866.

\section{Kualitas hadis}

Imam

at-Tarmidzi

mengatakan, Hadis ini sebagaimana yang di dengarnya dari Imam Bukhari yaitu ghairu Mahfuz dan Shohih. Sedangkan Imam Ahmad dan Ibnu Hibban mengatakan bahwa hadis ini riwayatnya sesuai dengan syarat shohih yang ditetapkan oleh bukhori dalam kitab Shohihnya. ${ }^{11}$

Sedangkan Syekh

Muhammad Nashiruddin alAlbani berkata; Hadist ini Hasan Shahih di dalam kitab al-irwaa no. 1885, dan Shahih Abu Daud no. 1939.12

\section{Hadis-hadis Lain tentang}

\section{Poligami}

1. Hadis yang berkaitan dengan berlaku adil dalam poligami

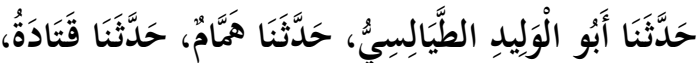

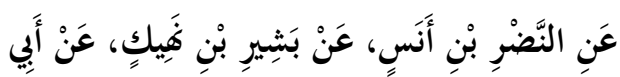

${ }^{11}$ Ibnu Mulqin, Badrul Munir (Beirut: Dar al-Kutub al-Ilmiyah, 1971), 108 - 109.

${ }^{12}$ Muhammad Nashiruddin Al Albani, Shahih Sunan At-Tirmidzi..., 213. 




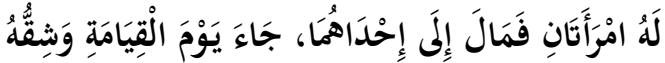
(HR. Abu Daud.no2133). مَائلِ

2. Hadis tentang maksimal istri 4 orang

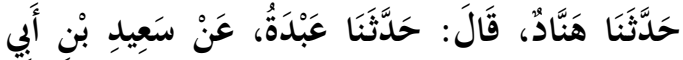

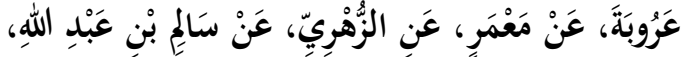

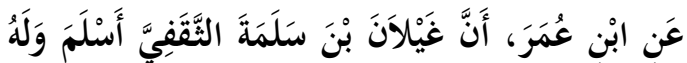

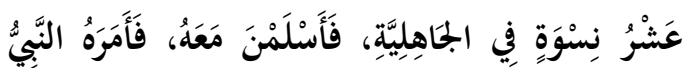

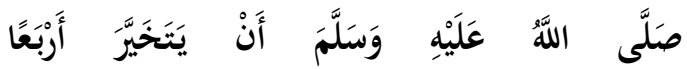
مِنْهُنَّ)

3. Hadis larangan Poligami

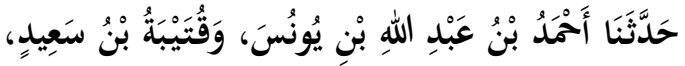

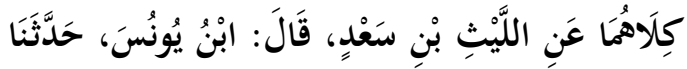

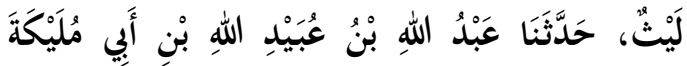

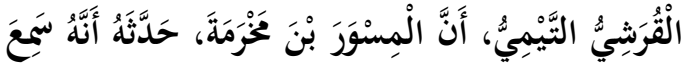

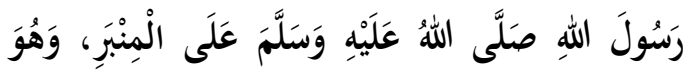

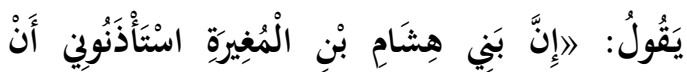

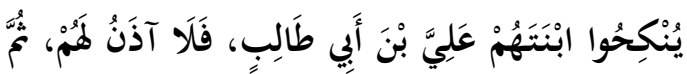

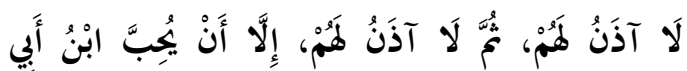

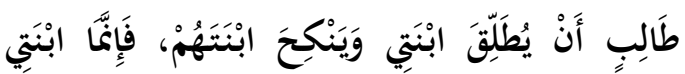

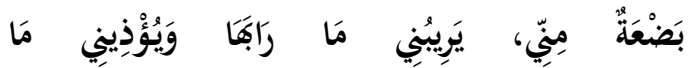
آذَاهَا(HR.Muslim, no.2449).

\section{Komentar Ulama}

Malik berpendapat: memilih diantara mereka (istri-istri) empat orang dan juga sama dengan Syafi'i, Ahmad dan Abu Daud. Sedangkan Abu Hanifah, Ast-tsuar, dan Ibni Abi Lail berpendapat : memilih mereka para istri yang pertamatama kali diakad nikahi. ${ }^{13}(\mathrm{Ibnu}$ Rusyd : 37)

Secara eksplisit hadis Tirmidzi, Ibn Majah dan Ahmad menunjukkan bolehnya berpoligami dengan ketentuan tidak boleh lebih dari empat. Seandainya poligami tidak boleh mestinya Nabi memerintahkan Ghailan memilih salah satu saja dari sepuluh orang istrinya dan menceraikan yang lain. Ini menunjukkan bahwa batasan maksimal seorang laki-laki yang berpoligami adalah empat orang istri.

${ }^{13}$ Ibnu Rusyd, Bidayatul Mujtahid wa Nihayatul Muqtashid, (Beirut: Dar al-Fikri, 2005), 37. 
Namun, apakah bolehnya berpoligami itu mutlak untuk semua orang tanpa ada ketentuan dan syarat yang harus dipenuhi. Apabila kita baca surat An-Nisa' ayat 3 dan korelasi dengan hasits-hadis lain, seperti hadis tentang pelarangan Ali yang hendak melakukan poligami, serta ancaman Rasulullah SAW bagi seorang suami yang tidak dapat berlaku adil terhadap isteri-isterinya sebagaimana tersebut di atas, maka dapat dipahami bahwa Islam tidak memerintah, apalagi mewajibkan poligami, dan tidak memberikan kesempatan yang longgar kepada kaum Muslimin untuk berpoligami. Artinya, seorang yang hendak berpoligami harus memenuhi syarat dan ketentuan yang berlaku.

Banyak penafsiran mengapa Nabi Saw melarang putrinya dipoligami Ali bin Abi Thalib ra adalah putri Abu Jahl bin Hisyam, musuh Allah Swt dan musuh Nabi Saw. tetapi beberapa penafsiran lain menyebutkan memang karena Nabi Saw tidak menginginkan putri beliau Fathimah ra dipoligami dengan siapapun, karena poligami itu menyakiti hatinya, dan yang menyakiti hatinya juga menyakiti hati Nabi Saw. Karena itu, seperti dinyatakan Ibn Hajar al-'Asqallani, ada ulama yang menyatakan bahwa poligami bisa saja dilarang jika bisa menimbulkan kerusakan dan kezaliman, tentu terhadap perempuan dan anak-anak.

\section{Poligami Perspektif Ali Mustofa Ya'Qub}

a. Sosiokultural dan Pengembaraan Ilmu Ali Musofa Ya'qub

Kiai Ali Mustafa Yaqub lahir di desa Kemiri, Kecamatan Subah, Kabupaten Batang, Provinsi Jawa Tengah, bertepatan dengan tanggal 2 Maret 1952. Ayahnya bernama H. Yaqub, seorang religius dan pendak-wah terkemuka pada zamannya dan Imam di masjid-masjid di Jawa Tengah.. Ibunya bernama Hj. Siti Habibah, seorang 
ustadzah dan ibu rumah

tangga.

Dalam

kesehariannya, ibunya ikut

membantu perjuangan

suaminya.

Ibunya

meninggal pada tahun

1996. Istri Kiai Ali

Mustafa bernama $\mathrm{Hj}$.

Ulfah Uswatun Hasanah.

Anaknya yang semata

wayang bernama $\mathrm{H}$. Ziaul

Haramain Ali Mustafa, Lc.

Kiai Ali Mustafa Yaqub

anak kelima, memiliki

delapan saudara, dari

delapan bersaudara

tersebut dua di antaranya

meninggal dunia, dan

yang masih hidup lima

bersaudara, salah satu dari

kakaknya bernama $\mathrm{KH}$.

Ahmad Dahlan Nuri

Yaqub mengikuti jejak

ayahnya sama dengan

beliau, dan sekarang

kakaknya sebagai Pengasuh

Pondok

Pesantren
Darussalam di Batang, Jawa

Tengah. ${ }^{14}$

Pada tahun 1976, atas beasiswa penuh dari pemerintah Arab Saudi, ia mencari ngelmu lagi di

Fakultas Syariah

Universitas Islam Imam

Muhammad bin Saud, Riyadh, Saudi Arabia sampai tamat dengan mendapatkan Ijazah (syahâdat) Licence, tahun 1980. Kemudian masih di kota yang sama ia melanjutkan dirasatnya lagi di Universitas King Saud, Departemen Studi Islam Jurusan Tafsir dan Hadis tahun 1980, sampai tamat dengan ijazah Master, tahun 1985. Dipilihnya Fakultas Syariah (S1) dan Departemen Tafsir Hadis (S2) oleh Kiai Ali Mustafa Yaqub bukan sebuah

${ }^{14}$ Ali Mustafa Yaqub, Hadis-hadis Palsu Seputar Ramadhan (Jakarta: Pustaka Firdaus, 2003), 143. 
kebetulan, akan tetapi karena

dalam

pandangannya kedua ilmu

tersebut sangat diperlukan

oleh masyarakat luas. Pada

tahun-tahun Kiai Ali

Mustafa Yaqub di Arab

Saudi, program S3 Doktoral

belum dibuka pada

Universitas-Universitas di

Riyadh. Hal tersebut karena rendahnya minat orang Arab Saudi untuk kuliah S2 waktu itu. Pihak Universitas hanya bersedia untuk membuka program doktor dengan syarat mahasiswa asli Saudi harus lebih dari 50 persen. Akan tetapi, saat itu dari 20 orang mahasiswa program Magister di Universitas King Sa'ud Riyadh hanya berjumlah 2 orang saja yang asli Saudi sehingga program S3 tidak bisa diadakan. Kondisi ini membuat Kiai Ali Mustafa Yaqub tidak bisa langsung melanjutkan kuliahnya pada program doktor, sehingga akhirnya ia memutuskan untuk pulang ke Indonesia. Tahun itu juga ia pulang ke tanah air, dan kemudian mengajar di Institut Ilmu Al-Qur'an (IIQ) Jakarta, Institut PTIQ Jakarta, Pengajian Tinggi Islam Masjid Istiqlal, Pendidikan Kader Ulama (PKU) MUI, Sekolah Tinggi Ilmu Dakwah (STIDA) AlHamidiyah Jakarta, Institut Agama Islam Shalahuddin al-Ayyubi (INISA), Tambun, Bekasi dan IAIN Syarif Hidayatullah Jakarta. ${ }^{15}$ ( Hartono :2009)

b. Kontruksi Pemikiran Hadis Ali Mustofa Ya'qub

Jika kita Berbicara mengenai hadis, pada dasarnya relatif akan sangat

15 Hartono, Perkembangan Pemikiran Hadis Kontemporer di Indonesia: Studi atas Pemikiran Abdul Hakim Abdat dan Ali Mustafa Ya'qub (Jakarta: Sekolah Pascasarjana UIN Syarif Hidayatullah Jakarta, 2009), 84. 
luas karena ia memang terdiri dari berbagai komponen dan tema bahasan, mulai dari kajian atau kritik sanad (naqd alsanad), matan (naqd al-matn), hingga pemahaman hadis (fahm al-hadi, fgh al-hadis। atau máani al-hadis). Dari ketiga komponen atau tema ini, kaitannya dengan kajian penulis, tulisan ini hanya akan difokuskan pada tema yang terakhir yakni pemahaman hadis; tema yang berbeda tidak ikut menjadi bahasan kecuali hanya sebagai pelengkap atau saat diperlukan. Dalam konteks ini tentu yang menjadi fokus tokohnya adalah Ali Mustafa Yaqub sebagaimana tercermin dalam judul dan sub judul di atas.

Dalam konstruksi pemahaman hadis, Ali Mustafa Yaqub menyebutkan bahwa pada dasarnya hadis Nabi harus dipahami secara tekstual atau apa adanya (lafziyyah). Jika tidak memungkinkan, maka sebuah hadis diperbolehkan untuk dipahami secara kontekstual. ${ }^{16}$ ( Ali Mustofa Ya'qub : 2006, 152) Menurut Ali Mustafa, hadis-hadis yang mestinya dipahami secara tekstual adalah hadis yang berkenaan dengan perkara gaib (al-umur alga'ibiyyah) dan ibadah murni (al-ibadah al-mahd\}ah). Dengan lebih terperinci mengenai perkara gaib, Ali Mustafa menyebutkan bahwa perkara gaib dapat dibedakan menjadi dua kategori: pertama, gaib yang relatif ( $g a^{\prime} i b$ nisbi); seperti keberadaan Kota New York. Bagi orang yang belum berkunjung, kota tersebut masih disebut gaib tetapi 
tidak demikian halnya bagi

orang yang pernah

berkunjung ke sana. ${ }^{17}$ ( Ali

Mustofa Ya'qub : 2006, 21)

Kedua, gaib mutlak (ga'ib

haqiqi), seperti perihal

datangnya hari Kiamat,

hakikat Allah, surga, neraka

dan sebagainya. Untuk hal

hal seperti ini seyogianya cukup dengan mengikuti

petunjuk al-Qur'an dan hadis Nabi. Tidak ada ruang untuk ditafsirkan secara kontekstual.

\section{Kaitannya dengan}

ibadah murni (al-ibadah almahdah), seperti tata cara salat, puasa, haji dan sebagainya yang merupakan persoalan antar Tuhan dengan hamba-Nya, menurut Ali Mustafa juga tidak layak dipahami secara kontekstual. Teks-teks yang berkaitan dengan hal ini

${ }^{17}$ Ali Mustofa Ya'qub, Haji Pengabdi Setan $_{, \ldots}, 21$ harus dipahami apa adanya sesuai petunjuk Al-Qur'an dan hadis Nabi. Lebih jauh Ali Mustafa menyebutkan bahwa upaya

kontekstualisasi

(memahami secara kontekstual) ibadah murni bisa mengakibatkan substansi teks tersebut kehilangan nilai universalitasnya, misalnya masing-masing lingkungan atau negara akan membuat aturan salat sesuai kondisinya.

Selanjutnya mengenai pemahaman hadis secara kontekstual, Ali Mustafa Yaqub menjelaskan bahwa hadis yang dimaksud harus dipahami dengan melihat aspek-aspek di luar teks itu sendiri; meliputi: pertama: sebab-sebab yang melatarbelakangi (asbab wurud al-hadis). Bagi Ali Mustafa, mengetahui sebabsebab yang 
melatarbelakangi

munculnya sebuah hadis

tergolong sesuatu yang sangat urgen untuk mendapatkan pemhaman yang proporsional dan tepat. Sebagai contoh terkait hadis yang menyebutkan bahwa Nabi bersabda, "Apabila kalian akan menunaikan salat Jumat, hendaklah mandi terlebih dahulu." Berkenaan dengan hadis ini, Ali Mustafa menjelaskan bahwa sebenarnya hadis ini memiliki sebab khusus. Kala itu, perekonomian para sahabat pada umumnya masih terbilang sulit sehingga mereka hanya memakai baju wol yang kasar dan jarang dicuci. Di sisi lain, sebagian besar profesi mereka adalah sebagai petani. Setelah berladang, banyak di antara mereka yang langsung pergi ke masjid

untuk menunaikan salat Jumat. Singkat cerita, aroma tidak sedap pun menyeruak dan sangat mengganggu para jamaah lain termasuk Nabi. Tidak heran apabila kemudian beliau bersabda seperti di atas. Dengan memperhatikan kondisi social yang melatarbelakangi sabda di atas, Ali Mustafa menyimpulkan bahwa Nabi hanya mewajibkan mandi Jumat bagi orang yang badannya kotor saja. ${ }^{18}$

Kedua, lokal dan temporal (makani wa zamani). Dalam hal ini Ali Mustafa memberikan contoh hadis yang berbunyi, "Antara timur dan barat adalah kiblat." Untuk masyarakat Madinah yang secara goegrafs berada di sisi utara kabah (Mekkah) 
pamahaman tekstual

terhadap hadis di atas

pastinya sangat tepat.

Namun untuk konteks

Indonesia yang secara

geografs memang berbeda

dengan Madinah, maka tidak ayal lagi, hadis ini harus dipahami secara kontekstual disesuaikan dengan letak geografs Indonesia. Dengan kata lain, dalam hal ini pertimbangan aspek lokalitas dan temporalitas sebuah hadis mutlak diperlukan.

Ketiga, hubungan kausalitas ('llah al-kalam). Dalam poin ini Ali Mustafa mencontohkan sebuah hadis yang berbunyi, "Seandainya tidak ada Bani Israil maka makanan tidak akan menjadi basi dan daging tidak akan membusuk. Seandainya tidak ada Hawa' maka tidak akan ada istri yang berkhianat kepada suaminya." Hadis ini menurut Ali Mustafa tidak bisa dipahami secara konkrit kecuali dengan mempertimbangkan pendekatan kontekstual yaitu bahwa sebenarnya hadis ini merupakan kritik Nabi atas kekikiran orangorang Yahudi yang tidak mau memberikan makanannya pada orang lain padahal mereka sendiri tidak siap menghabiskannya hingga makanan itu pun membusuk.

Keempat, sosio-kultural (taqalid). Sosio-kultural yang dimaksudkan Ali Mustafa dalam konteks hadis adalah dengan mengaitkan hadis yang dimaksud dengan kondisi sosial masyarakat pada waktu itu. Misalnya berkenaan dengan sabda Nabi memperbolehkan orang salat meludah di masjid. Ali menjelaskan bahwa meludah di masjid 
kala itu tidak menjadi

persoalan yang serius

karena masjid pada waktu

itu masih beralas pasir atau

debu sehingga ludah yang

jatuh akan cepat terserap.

Selain itu, pasir Arab dengan udara kering dan

panas bisa menyebabkan

bakteri tidak bisa bertahan

lama. Kondisi ini tentunya

berbeda sekali dengan

realitas hari ini, lantai

masjid sudah beralas

keramik atau marmer.

Meludah di masjid justru

akan megnotori dan

membahayakan kesehatan

bahkan masjid bisa menjadi

tempat yang sangat

menjijikkan sehingga pada

gilirannya akan sulit

diminati.

c. Poligami perspektif Hadis:

Telaah Pemikiran Ali

Mustofa Ya'qub

$\begin{array}{crr}\text { Berbicara } & \text { mengenai } \\ \text { pemikiran Ali } & \text { Musofa }\end{array}$
Ya'qub mengenai Poligami, maka terlebih dahulu kita akan membahas bagaimana pandangannya mengenai pernikahan. Menurut Ali Musotofa Ya'qub Ada tiga macam pernikahan yang sah menurut hukum Islam, namun oleh sebagian orang, khususnya kelompok liberal, hal itu selalu dipermasalahkan. Tiga pernikahan itu adalah; 1) poligami, 2) nikah sirri (pernikahan yang tidak dicatat di KUA), dan 3) nikah di bawah umur. Ketiga pernikahan ini dipandang dari sudut agama islam, apabila dilaksanakan sesuai dengan ketentuan-ketentuan dalam hukum Islam, maka pernikahan tersebut adalah sah.

\section{Sehingga}

konsekuensinya suami isteri ketika melakukan hubungan seksual sudah 
halal, bukan zina, dan apabila dari hubungan suami istri itu melahirkan anak maka anak tersebut juga sah menurut hukum islam. Ia bernasab kepada ayahnya, dan ketika ayahnya meninggal ia mendapatkan hak waris.

Bahkan pembahasan mengenai Poligami diatur dalam undang-undang yang berlaku yaitu Didalam Pasal 49 Undang-undang Nomor 7 Tahun 1989 yang telah diubah dengan Undangundang No. 3 Tahun 2006 dan perubahan kedua dengan Undangundang Nomor 50 tahun 2009 menyatakan bahwa "Pengadilan Agama bertugas dan berwenang memeriksa, memutus, dan menyelesaikan perkara di tingkat pertama Antara orang-orang yang beragama Islam dibidang: perkawinan, waris, wasiat, hibah, wakaf, zakat, infaq, shadaqah, dan ekonomi syari'ah.

Pada penjelasan Pasal 49 alinea kedua dijelaskan pula bahwa yang dimaksud dengan "antara orang-orang yang beragama Islam" adalah "termasuk orang atau badan hukum yang dengan sendirinya menundukkan diri dengan suka rela kepada hukum Islam mengenai hal-hal yang menjadi kewenangan Peradilan Agama sesuai dengan ketentuan pasal ini". Kemudian pada penjelasan huruf a pasal ini dinyatakan bahwa yang dimaksud dengan "perkawinan" adalah "halhal yang diatur dalam atau berdasarkan undangundang mengenai perkawinan yang berlaku yang dilakukan menurut syari'ah", yang antara lain adalah "izin beristeri lebih 
dari seorang".19( Reza Fitra

Ardhian dkk : 2015)

Sebagai seorang tokoh pemerhati hadis kenamaan, Ali Mustofa Ya'qub menyadari bahwa terdapat hadis yang membicarakan mengenai masalah Poligami ini. Meskipun tidak di sebutkan secara implisit mengenai hukum poligami tersebut. Setelah kita melihat bagaimana kontruksi pemahaman hadis yang diterapkan oleh Ali Mustofa dalam mengambil kesimpulan hukum yang terdapat dalam hadis. maka, bisa kita bisa menerapkan kontruksi tersebut untuk melihat bagaimana Ali pandangan Ali Mustofa mengenai Poligami.

${ }^{19}$ Reza Fitra Ardhian, Satrio Anugrah, Setyawan Bima, Poligami dalam Hukum Islam dan Hukum Positif Indonesia serta Urgensi Pemberian Izin Poligami di Pengadilan Agama, Jurnal Privat Law II Vol. III no. 2 Juli-Desember (2015), 25.
Pertama, melihat asbabbul wurud hadis mengenai Poligami. Jika kita perhatikan beberapa hadis yang membolehkan Poligami bercerita mengenai salah seorang sahabat Nabi yang masuk Islam yang mana ia memiliki 10 istri sebelum ia masuk islam. Ketika ia masuk islam, nabi menyuruhnya untuk memilih empat diantaranya serta menceraikan yang lainnya. Jadi ini berimplikasi bahwa sebenarnya ini bukanlah kebolehan untuk melakukan Poligami. Hal ini di perkuat dengan hadis yang menyatakan bahwa Nabi melarang Ali untuk mempoligami anaknya yaitu Fatimah binti Muhammad.

Kedua, jika kita membawa isu poligami ini keranah keindonesiaan. Sangat tidak relevan Karena 
sebagian besar masyarakat

indonesia

masih

menganggap

bahwa

poligami merupakan salah

satu perilaku yang akan

menyiksa kaum perempuan

serta dianggap sebagai

pelecehan terhadap hak-hak

perempuan.

Ketiga, jika kita melihat praktek poligami yang dilakukan oleh Rasul bahwa beliau melakukan itu sebagai sarana dakwah serta menjaga kaum perempuan yang sebagian besar ditinggal mati oleh suaminya karena berjuang di medan perang. Ini terbukti bahwa dari semua istri rasul, Cuma Aisyah sendiri yang dinikahi masih dalam keadaan gadis atau perawan. Sehingga praktek poligami yang di praktekkan sekarang ini sangat menyalahi dari apa yang diajarkan oleh rasul karena sebagian besar alasan yang dilontarkan oleh orang yang melakukannya hanya sebatas syahwat semata.

Keempat, cara keempat yang mesti kita terapkan dalam kontruksi pemahaman hadis Ali Mustofa Ya'qub adalah dengan melihat SosioKultural saat hadis itu muncul. Sebagian besar hadis yang dijadikan dalil dalam poligami muncul pada masa awal islam yang bisa dikatakan bahwa hal tersebut juga merupakan salah satu sarana dakwah yang di terapkan oleh Nabi Muhammad SAW untuk menguatkan pondasi agama islam yang waktu itu masih lemah.

Setelah kita menerapkan metode atau cara yang diterapkan Ali Mustofa Ya'qub terhadap hadis. maka kita akan beranggapan bahwa ia akan 
menolak pelaksanaan

Poligami. Akan tetapi dalam kenyataannya, sebagaimana yang dituliskannya mengenai permasalahan poligami di Majalah Nabawi mengenai penolakannya terhadap serangan aktifis yang menyerang orang yang melakukan praktek Poligami. Ia bisa dikatakan setuju dengan praktek poligami karena ia mengambil sikap tekstualis dalam memahami hadis mengenai poligami.

\section{Simpulan}

Berdasarkan pemaparan di atas. Kita dapat mengambil kesimpulan bahwa jika kita menerapkan secara konsisten kontruksi hadis yang diterapkan oleh Ali Mustofa Ya'qub. Maka kita akan mendapatkan pemahaman bahwa Poligami pada dasarnya memang ada teks agama yang menyatakannya, tetapi bukan berati teks itu memerintahkannya dan juga tidak melarang, Poligami memang pernah di lakukan oleh
Rasulullah Saw tapi dengan tujuan syiar Islam bukan karena hasrat seksual, ataupun menunjukkan kekuasaan laki-laki atas perempuan. Akan tetapi perkembangan pada masa-masa berikutnya malah menjadi sebalik nya.

Poligami dalam berbagaikasus secara umum melahirkan berbagai bentuk kekerasan dan ketidakadilan terhadap perempuan. Bila kenyataannya terjadi sebagaimana diuraikan di atas, maka kesuksesaan praktek poligami bukan bergantung pada keadilan laki-laki, tetapi lebih kepada kemampuan laki-laki( suami) untuk menjadikan perempuan (istri) tunduk dan pasrah atas nama otoritasnya sebagai suami dan kepala rumahtangga. Hal ini sangatlah berbeda dengan paraktek poligami yang dilakukan Nabi dengan motif dakwah dan melindungi serta memulikan wanita. 
DAFTAR PUSTAKA

Abdurrahman I. Doi, Women in Syari"ah (Islamic Law) Malaysia: A.S. Noordeen, 1992

Al Albani, Muhammad Nashiruddin, Shahih Sunan at-Tirmidzi, terj Ahmad Yuswaji, Cet I, Jakarta: Pustaka Azzam, 2003

Ardhian, Reza Fitra, Satrio Anugrah, Setyawan Bima, Poligami dalam Hukum Islam dan Hukum Positif Indonesia serta Urgensi Pemberian Izin Poligam di Pengadilan Agama, Jurnal Privat Law II Vol. III No 2 Juli-Desember 2015

As-Sijistani, Abu Dawud Sulaiman bin Al-Asy'ats, Sunan Abu Daud, Beirut: Daar al-Kutub al-A'rabi, 1996

At-Tirmidzi, Abu Isa Muhammad bin Isa bin Saurah, Sunan atTarmidzi, Beirut: Dar al-Gharbi al-Islami, 1998

Departemen Pendidikan Nasional, Kamus Besar Bahasa Indonesia Pusat Bahasa, Edisi. iv, Jakarta: PT. Gramedia, 2008

Dhofier, Zamakhsyari, Tradisi Pesantren: Studi Pandangan Hidup Kyai dan Visinya Mengenai Masa Depan Indonesia, Edisi Revisi, Jakarta: LP3ES, 2015

Haikal, Abduttawab, Rahasia Perkawinan Rasulullah saw.:
Poligami dalam Islam vs. Monogami Barat, alihbahasa Ilyas Ismail al-Sendany. Cet. I; Jakarta: Pedoman Ilmu Jaya, 1993

Hartono, Perkembangan Pemikiran Hadis Kontemporer di Indonesia: Studi atas Pemikiran Abdul Hakim Abdat dan Ali Mustafa Ya'qub, Jakarta: Sekolah Pascasarjana UIN Syarif Hidayatullah Jakarta, 2009

Isma'il, Nurjanah, Perempuan dalam Pasungan, Yogyakarta: LKIS Yogyakarta, 2003

Kuzari, Achmad, Nikah sebagai Perikatan, Jakarta: PT Raja Grafindo, 1995

Mahyuddin, Masailul Fiqhiyah, Jakarta: Kalam Mulia, 2003

Makmun, A. Rodli dan Evi Muafiah (ed), Poligami dalam Penafsiran Muhammad Syahrur, Ponorogo: STAIN Ponorogo Press, 2009

Miski, Pemahaman Hadis Ali Mustafa Yaqub (Studi atas Fatwa Pengharaman Serban dalam Konteks Indonesia), Riwayah: Jurnal Studi Hadis Volume 2 No. 12016

Mulqin, Ibnu, Badrul Munir, Beirut: Dar al-Kutub al-Ilmiyah, 1971

Muslim, al-Hajjaj Abu al-Hasan alQusyairy an-Naisabury, Shohih Muslim, Beirut: Dar ihya' atTurats al-A'rabiy 
Rusyd, Ibnu, Bidayatul Mujtahid wa Nihayatul Muqtashid, Beirut: Dar al-Fikri, 2005

Suprapto, Bibit, Liku-liku Poligami, Yogyakarta: Al-Kautsar, 1990

Yaqub, Ali Mustafa, Sejarah dan Metode Dakwah Nabi, Jakarta: Pustaka Firdaus, 2000

\begin{tabular}{lcc} 
& Hadis-hadis \\
Palsu & Seputar & $\begin{array}{c}\text { Ramadhan, } \\
\text { Jakarta: }\end{array}$ \\
\hline
\end{tabular}
Haji Pengabdi

Setan, Jakarta: Pustaka Firdaus, 2006 